\title{
OPEN BEDSIDE TRACHEOSTOMY: ROUTINE PROCEDURE FOR PATIENTS UNDER PROLONGED MECHANICAL VENTILATION
}

\author{
Ricardo Mingarini Terra ${ }^{1,2,3,4}$, Angelo Fernandez $z^{1,2,3}$, Ricardo Helbert \\ Bammann $^{2,3,4,5}$, Ana Cristina P. Castro ${ }^{2,3,4}$, Augusto Ishy ${ }^{1,2,3,4}$, Jader Joel Machado \\ Junqueira ${ }^{1}$
}

Terra RM, Fernandez A, Bammann RH, Castro ACP, Ishy A, Junqueira JJM. Open bedside tracheostomy: routine procedure for patients under prolonged mechanical ventilation. Clinics. 2007;62(4):427-32.

BACKGROUND: Tracheostomy is electively performed in critically ill patients requiring prolonged respiratory support. The risk of transporting, the increasing associated cost and operative room schedule are some of the obstacles for wider acceptance of this procedure. The use of rigid selection criteria exclude many patients who would benefit of this approach.

OBJECTIVE: To determine the safety of open bedside tracheostomy (OBT) as a routine intensive care units (ICU) procedure without any selection criteria, considering its peri and postoperative complications.

METHOD: Retrospective medical chart review of all patients that underwent elective tracheostomy between April 1999 and December 2005 at ICU of three private hospitals.

RESULTS: The study group comprised 552 patients with a mean age of $69.6 \pm 15.8$ years. The incidence of significant complications (until 30 days after the procedure) was 4.34\% (24 cases): 9 minor bleeding, 9 major bleeding, 2 subcutaneous emphysema, 4 stomal infections. Late complications were: laryngotracheal stenosis in 2 and tracheoinomminate fistula in 1 patient.

CONCLUSIONS: OBT seems to be a safe and simple procedure, when performed by a team of experienced physicians under controlled circumstances, and should be considered as an option for ICU patients.

KEY WORDS: Tracheostomy. Intraoperative Complications. Postoperative Complications. Intensive Care Units. Thoracic Surgery.

\section{INTRODUCTION}

Tracheostomy is electively performed in critically ill patients requiring prolonged respiratory support or frequent bronchopulmonary toilet, or to help with weaning from mechanical ventilation. It is better tolerated than oral or nasal tracheal intubation and is thought to reduce sedation requirements and time in the intensive care unit (ICU). ${ }^{1-6}$

Traditionally, elective tracheostomy has been performed in the operating room (OR) by using the standard surgical

\footnotetext{
${ }^{1}$ Hospital das Clínicas, University of São Paulo Medical School - Thoracic Surgery - São Paulo/SP, Brazil.

${ }^{2}$ Hospital 9 de Julho - Thoracic Surgery

${ }^{3}$ Hospital Santa Paula - Thoracic Surgery

${ }^{4}$ Hospital Santa Virgínia - Thoracic Surgery

${ }^{5}$ Instituto de Infectologia Emílio Ribas - Thoracic Surgery

Email: rmterra@uol.com.br

Received for publication on January 25, 2007

Accepted for publication on April 23, 2007
}

techniques originally described by Jackson. ${ }^{7}$ Ciaglia et $\mathrm{al}^{8}$ described a percutaneous dilational tracheostomy (PDT) based on a model proposed by Seldinger for endovascular intervention procedures. ${ }^{9}$ This technique, described as a bedside procedure, has found widespread acceptance as an alternative method to the conventional open procedure, since it eliminates risks associated to transporting critically ill patients and decreases costs related to the operating room. ${ }^{1,2,10-12}$ Both methods have been compared to assess their clinical (morbidity and mortality), surgical (technique), and/or financial (cost) differences, ${ }^{1-6,10-14}$ but results are controversial, and there are insufficient data to establish a clear superiority of the PDT technique.

The concept of bedside tracheostomy is attractive, and surgeons have started performing open bedside tracheostomies (OBT). This approach has proved to be safe in selected patients. ${ }^{15-19}$ In a prospective randomized study, Massick et $\mathrm{al}^{19}$ found excellent results and stated that OBT represents 
the standard of care in bedside tracheostomy, since it provides a more secure airway at markedly reduced patient charge. However, the use of very rigid selection criteria excluded many patients who might have benefited from this approach. No evidence supports these exclusion criteria, and it is not clear whether they are really necessary.

The primary objective of this study was to determine the safety of OBT as a routine ICU procedure without any selection criteria, considering its peri- and postoperative complications.

\section{METHOD}

In April 1999, we established a bedside tracheostomy protocol, and from this date on, all elective tracheostomies of the medical and surgical ICUs of 3 private hospitals were performed as open bedside procedures. The 3 hospitals were general hospitals and had 250 (hospital 1), 148 (hospital 2), and 130 (hospital 3) beds; their ICUs had 50 (25 general/25 coronary), 40 (28 general/12 coronary), and 15 (all general) beds, respectively. A retrospective medical chart review was conducted including all patients who underwent elective ICU trachesotomies between April 1999 and December 2005 in hospital 1 and between October 2002 and December 2005 in hospitals 2 and 3. Indications and timing were decided by the intensivist team. This study was approved by the Institutional Ethical Committees; informed consent was considered not necessary. No selection criteria (age, anatomic landmarks, history of difficult translaryngeal intubation, etc) at all were adopted.

The surgical team comprised 5 senior thoracic surgeons with airway expertise (endoscopy and airway surgery training). In all tracheostomies, 2 surgeons scrubbed and performed the procedure. The procedure was assisted by an ICU nurse and a respiratory therapist. Both of them were previously trained and knew of all necessary materials and surgical steps. An intensivist was present to sedate and monitor the patient.

The ICU bed is a particular problem, since sometimes its width makes exposure difficult, compelling the surgeon to assume a very uncomfortable position. All ICU beds were of standard size $(2.35 \mathrm{~m}$ x $0.90 \mathrm{~m}$ x $0.45-0.70 \mathrm{~m})$. In all procedures, a 4-bulb mobile surgical operation light (12 000 lux per bulb) was used, allowing good anatomical visualization even in deep incisions. The material was standardized and checked before every procedure.

Coagulation disturbances, if present were appropriately corrected to permit the surgical approach. Before the procedure, the patient's ventilation was changed to a set rate of at least 10 , and $\mathrm{FiO}_{2}$ was increased to $100 \%$. Intravenous sedation was employed with midazolam and fentanila
Hemodynamic parameters and pulse oximetry were monitored constantly throughout the procedure. A respiratory therapist was always present to insure respiratory care and to help with extubation.

After anterior neck infiltration with $2 \%$ lidocaine, a $3-\mathrm{cm}$ longitudinal incision was done; the procedure was performed as already standardized in the literature. Proper positioning of the tube was confirmed by demonstrating symmetric movement of the chest wall and maintenance of normal airway pressures, expiratory volumes, and satisfactory oxygen saturations on the pulse oximeter. Cuffed tracheostomy tubes (Shiley ${ }^{\circledR}$ or Portex $\left.{ }^{\circledR}\right)$ were used in all patients, and tube sizes varied from 7.0 to 9.0. Chest radiography was obtained the next day following the ICU routine to confirm appropriate tracheostomy placement and evaluate for pneumothorax.

Complications of OBT were recorded up to 30 days after the procedure. Stomal or endotracheal bleeding related to the procedure was considered significant (major) only if operative room (OR) exploration and/or blood transfusion was required; both intraoperative and postoperative bleeding were equally considered in the analysis. Bleeding was considered minor when controlled by digital compression, electrocautery, or gauze packing in the ICU, and only postoperative minor bleeding was analyzed. Stomal infection was diagnosed when cellulitis around the stoma was present.

Cost estimation for the open bedside procedure, OR open procedure, and percutaneous bedside procedure was provided by the Financial Department of hospital 1. This cost estimate included surgeons' fees, materials, drugs and kits, bronchoscopy, and OR taxes when applicable.

\section{RESULTS}

The study group comprised 552 patients (321 men and 231 women) with a mean age of $69.6 \pm 15.8$ years (range, 24 to 94 years). The distribution of patients among hospitals was as follows: $413(74.8 \%)$ in hospital 1, $74(13.4 \%)$ in hospital 2, and $65(11.8 \%)$ in hospital 3.

Major underlying diseases at admission to the ICU were neurological $(54.4 \%)$, cardiorespiratory (27.2\%), and polytraumatic $(6.5 \%)$. Significant associated diseases were morbid obesity in $8(1.45 \%)$ patients and neck injury in 20 $(3.62 \%)$. All patients were under mechanical ventilation through an orotracheal tube when assigned to the study. The mean operative time was 19 minutes (range: 8 to 70 minutes).

Regarding complications, 24 (4.34\%) occurred, as summarized in Table 1 . No major intra-operative complications such as cardiac arrest or accidents requiring OR exploration occurred. There were no deaths related to the procedure. No significant difference in complication rate was observed among the three studied institutions. Bleeding was 
the most common complication. In 9 patients, OR exploration was necessary, and in 1 of them blood transfusion was required. No major bleeding occurred during the procedure; all incidences were postoperative complications. The 9 patients with minor bleeding were managed in the ICU, as previously described. Most of the minor bleeding $(77.8 \%)$ was an immediate postoperative complication (less than 48 hours after the procedure), the remaining 2 cases occurred in the fourth and sixth postoperative days. Two patients developed significant subcutaneous emphysema; however, no cause was identified, and the emphysema spontaneously disappeared after 7 days.

Table 1 - Complications of open bedside tracheostomy (OBT) (up to 30 days postsurgery)

\begin{tabular}{lcc}
\hline Parameters & $\mathrm{n}$ & $\%$ \\
\hline Major bleeding & 9 & 1.63 \\
Minor bleeding & 9 & 1.63 \\
Subcutaneous emphysema & 2 & 0.36 \\
Stomal infection & 4 & 0.72 \\
Total & 24 & 4.34 \\
\hline
\end{tabular}

Stomal infection was diagnosed in 4 patients by the presence of cellulitis around the stoma. Two patients received broad spectrum antibiotics for 2 weeks with good outcome, and for the other two patients, both the broad spectrum antibiotics and abscess drainage with daily dressing using activated coal were necessary.

Laringotracheal stenosis was identified in 2 patients after decanulation failure. In both cases, the diagnosis was made after 60th postoperative day.

One patient developed a tracheoinnominate artery fistula 60 days after the procedure. The patient was treated by sternotomy and ligation of brachiocephalic trunk where a hole was identified. She died 10 days after surgery due to multiple organ failure.

Tracheal tube displacement and perforated cuff in the first 24 postoperative hours are potentially dangerous complications. These problems occurred in 10 cases $(1.8 \%)$ and were easily managed as soon as they were recognized.

Even though described in literature, some complications were not observed in this series, including pneumothorax, posterior tracheal wall lesion, tracheo-esophageal fistula, and accidental extubation. Unnoticed tracheal tube misplacement was also not observed.

Estimated costs were as follows: US \$253 for the open bedside procedure, US \$496 for the OR open procedure, and US $\$ 494$ to $\$ 840$ for the percutaneous bedside procedure (depending on the selected percutaneous kit).

\section{DISCUSSION}

Historically, tracheostomy procedures have been associated with high morbidity and mortality. So it has been thought that the procedure should be performed in the OR because of the need for adequate lighting, instruments, and support facilities. ${ }^{16}$ However, some problems must be handled under this circumstance, including the hazard of moving critically ill patients to OR, ${ }^{18}$ the associated cost, and the inconvenience of OR schedules. The PDT procedure popularized by Ciaglia et $\mathrm{al}^{8}$ helped to resolve some of these issues. It convinced surgeons and intensivists that tracheostomy could be done at the bedside. The good outcomes seen in several series led to a change in ICU practices worldwide. ${ }^{1,5,13}$ Comparative studies of PDT and OBT showed similar results regarding complications. . $^{3,4,6,11,12,17,19,20}$ Two recent meta-analyses ${ }^{21,22}$ showed similar rates of major periprocedural and long-term complications for both procedures. However, PDT was associated with a reduced incidence of wound infection (odds ratio $=0.28,95 \%$ confidence interval, 0.16 to $0.49, P<.0005$ ) when compared to surgical tracheostomy. ${ }^{22}$ Other outcome measures such as costs, procedure duration, and use of minimal resources (such as materials or staff) are still controversial ${ }^{2,6,19}$ due to methodological flaws such as selection bias (observed in nonrandomized studies ${ }^{3,4,6}$ ) or comparisons between heterogeneous groups (such as bedside PDT versus open tracheostomy performed either bedside or in the $\mathrm{OR}^{2,3,11,12}$ ).

The advantages of a bedside procedure are demonstrated in one of the cited meta-analyses ${ }^{22}$; reduced bleeding (odds ratio $=0.29,95 \%$ confidence interval, 0.12 to $0.75, P=$ .01 ) and mortality (odds ratio $=0.71,95 \%$ confidence interval, 0.50 to $1.0, P=.05$ ) were observed for PDT when compared to surgical tracheostomy performed in the OR (no difference was found when compared to OBT).

Unfortunately, exclusion criteria such as anatomic features (obesity and cervical features such as distance between cricoid and supraesternal notch), ${ }^{16,19}$ physicians preference, ${ }^{16}$ and/or higher $\mathrm{FiO}_{2}$ requirements, ${ }^{18}$ limit a more widespread use of bedside procedures (both PDT and OBT). In a bedside tracheostomy trial, 164 patients were eligible, but only 100 received the bedside procedure. ${ }^{19}$

Patients who had a neck injury or were morbidly obese were included in our series and probably would have been excluded if literature criteria had been used. Unfortunately, we were unable to identify how many more patients would have been assigned to OR tracheostomy based on literature criteria; because anatomical landmarks were not considered exclusion criteria, these data were not available in our medical charts. Despite this absence of selection criteria, our average procedure time and complication rate were similar to 
those now available for open tracheostomy performed either at bedside or in the operating room, as summarized in Table 2. Our median procedure time was 19 minutes, but a large range was observed (8-70 minutes). This can be explained by the fact that even patients with unfavorable anatomical features such as distance between cricoid and supraesternal notch were included. In these cases, dissection and tracheal exposition can be difficult and more time-consuming.

As in other series, the most frequent complication was bleeding. Initially our threshold for OR exploration was low. Nowadays, we handle bleeding in the ICU almost every time just by retracting the edges of the incision and placing a hemostatic stitch; otherwise, we fill the wound with gauze pieces soaked in adrenaline solution and take them out after 48 hours. Infection was rarely observed in this series.

We identified 3 crucial principles for good results with bedside tracheostomy. First, the team must be expert with tracheostomy. Many people think that tracheostomy is a simple procedure, and the least trained surgeon usually performs it. In the ICU, the consequences of inexperience may be disastrous. In our series, all tracheostomies were performed by senior thoracic surgeons, and all of them have airway skills. Cumulative experience is very important for managing complications. Second, team cooperation is essential. Nurse staff and respiratory therapists must be committed for successful outcomes. Third, the procedure must be standardized. There must be adequate lighting and material, and everyone involved must know all the procedural steps. When we started to perform bedside tracheostomies, we faced staff resistance, mainly as a consequence of lack of training. But after a rigid protocol was established, this problem was no longer observed. In the beginning, the Infection Control Group was concerned about the risk of infection for this bedside procedure, and we know that this is still a controversial issue for some specialists; however, less than a $1 \%$ infection rate was observed in the studied patients, similar to what is found in literature.

The least expensive procedure based on our cost estimation was OBT; however, a long-term comparative financial analysis should be done to confirm this finding.

Costs and risks associated with transport of critically ill patients were avoided with OBT. Furthermore, after a training period and step standardization, the OBT procedure proved to be very favorable for the surgical team, since OR schedules were no longer a concern. For this reason we could also respond more promptly to requests by the ICU staff.

Complications and costs of OBT were not compared to those of PDT or the standard OR procedure because after a good initial experience with OBT (very few complications and no worries about OR schedules or special material funding), we have abandoned the other techniques. However, the absence of a control group limits the power of our conclusions. The absence of some information such as APACHE II scores, ventilatory parameters, coagulation disorders, and intraoperative bleeding quantification are a consequence of incomplete recordings. Unfortunately, these gaps in the data also weaken our conclusions and prevent statistical analysis that would be of great interest.

Since our tracheostomy team is the reference for elective ICU tracheostomy, practically all tracheostomies performed during the study period were included in this series. Urgent cases, such as head and neck cancer patients with airway obstruction, as well as patients who underwent tracheostomy simultaneously with other surgical procedures (eg, exploratory laparotomy) were not included in this series. The studied population is very representative of most general ICU population candidates for elective tracheostomy, so we speculate that our results may be easily extrapolated to common clinical practice. Through one of the largest published experiences, we have shown that following the 3 basic principles described above, routine OBT is feasible, and specific inclusion criteria are probably unnecessary.

Table 2 - Reported complication rate of open tracheostomy

\begin{tabular}{|c|c|c|c|c|c|c|}
\hline Authors & $\begin{array}{l}\text { Total } \\
\text { Cases } \\
\text { (n) }\end{array}$ & $\begin{array}{c}\text { Open } \\
\text { Tracheostomy } \\
\text { (n) }\end{array}$ & $\begin{array}{c}\text { Complication } \\
\text { Rate } \\
(\%)\end{array}$ & $\begin{array}{c}\text { Major } \\
\text { Bleeding } \\
(\%)\end{array}$ & $\begin{array}{c}\text { Minor } \\
\text { Bleeding } \\
(\%)\end{array}$ & $\begin{array}{c}\text { Stomal } \\
\text { Infection } \\
(\%)\end{array}$ \\
\hline Bowen et al $(2001)^{4}$ & 213 & 139 & 2.8 & 0.7 & 0.7 & 1.4 \\
\hline Gysin et al (1999) ${ }^{12}$ & 70 & 35 & 34.2 & 0 & 11.4 & 8.5 \\
\hline Upadhyay et al (1996) ${ }^{16}$ & 470 & 470 & 8.9 & 4.3 & 0.6 & \\
\hline Wang et al (1999) ${ }^{17}$ & 204 & 204 & $<5.0$ & $<1.0$ & $<4.0$ & 0 \\
\hline Wease et al $(1996)^{18}$ & 204 & 204 & 6.8 & 1.0 & 2.4 & 0 \\
\hline Massick et al $(2001)^{19}$ & 100 & 50 & 4.0 & 2.0 & 0 & 0 \\
\hline Silvester et al $(2006)^{20}$ & 200 & 100 & 13.0 & 4.0 & 2.0 & 6.0 \\
\hline Present Study & 552 & 552 & 4.3 & 1.6 & 1.6 & 0.7 \\
\hline
\end{tabular}


We must seek the safest, simplest, and least expensive procedure, even if it looks old-fashioned. Open bedside tracheostomy seems to be a safe and simple procedure; it is cheaper than other techniques and should be considered as an option for ICU patients requiring tracheostomy.

\section{RESUMO}

Terra MR, Fernandez A, Bammann RH, Castro ACP, Ishy A, Junqueira JJM. Traqueostomia convencional a beira do leito: procedimento de rotina para pacientes em ventilação mecânica prolongada. CLINICS. 2007;62(4):427-32.

INTRODUÇÃO: A traqueostomia é um procedimento eletivo realizado em pacientes de unidades de terapia intensiva sob ventilação mecânica prolongada. $\mathrm{O}$ risco associado ao transporte, custos e dificuldades de agendamento cirúrgico são alguns obstáculos para uma maior aceitação da traqueostomia. O uso de rígidos critérios de seleção para a realização deste procedimento a beira do leito exclui muitos pacientes que se beneficiariam deste método.

OBJETIVO: Determinar à segurança da traqueostomia convencional a beira do leito como procedimento de rotina (sem a utilização dos critérios de seleção) em unidades de terapia intensiva, considerando as complicações intra e pósoperatórias.

MÉTODO: Revisão retrospectiva de prontuários de pacientes submetidos à traqueostomia eletiva nas unidades de terapia intensiva de três hospitais privados no período de abril de 1999 a dezembro de 2005.

RESULTADOS: Foram incluídos 552 pacientes com idade media de $69.6 \pm 15.8$ anos. A incidência de complicações pós-operatórias (até o $30^{\circ}$ pós-operatório) foi $4.34 \%$ (24 casos): 9 sangramentos leves, 9 sangramentos importantes, 2 enfisemas subcutâneos, 4 infecções do estoma. As complicações tardias observadas foram: estenose laringotraqueal em 2 pacientes e fistula traqueo-inominada em 1 paciente.

CONCLUSÃO: A traqueostomia convencional a beira do leito parece ser um procedimento simples e seguro quando realizado por equipe experiente em condições controladas, deve, portanto ser considerada como uma opção para pacientes em terapia intensiva sob ventilação prolongada.

UNITERMOS: Traqueostomia. Unidade de Terapia Intensiva. Complicações Intra-Operatórias. Complicações Pós-Operatórias. Cirurgia Torácica.

\section{REFERENCES}

1. Krishnan K, Elliot SC, Mallick A. The current practice of tracheostomy in the United Kingdom: a postal survey. Anaesthesia. 2005;60:360-4.

2. Freeman BD, Isabella K, Cobb JP, Boyle WA $3^{\text {rd }}$, Schmieg RE Jr, Kolleff $\mathrm{MH}$, et al. A prospective, randomized study comparing percutaneous with surgical tracheostomy in critically ill patients. Crit Care Med. 2001;29:926-30.

3. Bacchetta MD, Girardi LN, Southard EJ, Mack CA, Ko W, Tortolani AJ, et al. Comparison of open versus bedside percutaneous dilatational tracheostomy in the cardiothoracic surgical patient: outcomes and financial analysis. Ann Thorac Surg. 2005;79:1879-85.

4. Bowen CP, Whitney LR, Truwit JD, Durbin CG, Moore MM. Comparison of safety and cost of percutaneous versus surgical tracheostomy. Am Surg. 2001;67:54-60
5. Fikkers BG, Fransen GA, van der Hoeven JG, Briede IS, van den Hoogen FJ. Tracheostomy for long-term ventilated patients: a postal survey of ICU practice in The Netherlands [Published online ahead of print July 22, 2003]. Intensive Care Med. 2003:29:1390-3.

6. Grover A, Robbins J, Bendick P, Gibson M, Villalba M. Open versus percutaneous dilatational tracheostomy: efficacy and cost analysis. Am Surg. 2001;67:297-301; discussion 301-2.

7. Jackson C. Tracheostomy. Laryngoscope. 1909;19:285-90.

8. Ciaglia P, Firsching R, Syniec C. Elective percutaneous dilatational tracheostomy: A new simple bedside procedure: Preliminary report. Chest. 1985;87:715-9. 
9. Marx WH, Ciaglia P, Graniero KD. Some important details in techinique of percutaneous dilatational tracheostomy via the modified Seldinger technique. Chest. 1996;110:762-6.

10. Freeman BD, Isabella K, Lin N, Buchman TG. A meta-analysis of prospective trials comparing percutaneous and surgical tracheostomy in critically ill patients. Chest. 2000;118:1412-8.

11. Melloni G, Muttini S, Gallioli G, Carretta A, Cozzi S, Gemma M, et al. Surgical tracheostomy versus percutaneous dilatational tracheostomy. A prospective-randomized study with long-term follow-up. J Cardiovasc Surg. 2002;43:113-21.

12. Gysin C, Dulguerov P, Guyot JP, Perneger TV, Abajo B, Chevrolet JC. Percutaneous versus surgical tracheostomy: a double-blind randomized trial. Ann Surg. 1999;230:708-14.

13. Anon JM, Escuela MP, Gomez V, Garcoa de Lorenzo A, Montejo JC, Lopez J. Use of percutaneous tracheostomy in intensive care units in Spain. Results of a national survey [Published online ahead of print April 30, 2004]. Intensive Care Med. 2004;30:1212-5.

14. Dulguerov P, Gysin C, Perneger TV, Chevrolet JC. Percutaneous or surgical tracheostomy: a meta-analysis. Crit Care Med. 1999;27:1617-25.

15. Futran ND, Dutcher PO, Roberts JK. The safety and efficacy of bedside tracheostomy. Otolaryngol Head Neck Surg. 1993;114:707-11.
16. Upadhyay A, Maurer J, Turner J, Tiszenkel H, Rosengart T. Elective bedside tracheostomy in the intensive care unit. J Am Coll Surg. 1996;183:51-5.

17. Wang SJ, Sercarz JA, Blackwell KE, Aghamohammadi M, Wang MB. Open bedside tracheostomy in the intensive care unit. Laryngoscope. 1999;109:891-3.

18. Wease GL, Frikker M, Villalba M, Glover J. Bedside tracheostomy in the intensive care unit. Arch Surg. 1996;131:552-5.

19. Massick DD, Yao S, Powell DM, Griesen D, Hobgood T, Allen JN, et al. Bedside tracheostomy in the intensive care unit: A prospective randomized trial comparing open surgical tracheostomy with endoscopically guided percutaneous dilational tracheostomy. Laryngoscope. 2001;111:494-500.

20. Silvester W, Goldsmith D, Uchino S, Bellomo R, Knight S, Seevanayagam $\mathrm{S}$, et al. Percutaneous versus surgical tracheostomy: A randomized controlled study with long-term follow-up. Crit Care Med. 2006;34:214552.

21. Higgins KM, Punthakee X. Meta-analysis comparison of open versus percutaneous tracheostomy. Laryngoscope. 2007;117:447-54.

22. Delaney A, Bagshaw SM, Nalos M. Percutaneous dilatational tracheostomy versus surgical tracheostomy in critically ill patients: a systematic review and meta-analysis. Critical Care. 2006;10:R55. 